archives-ouvertes

\title{
Temperature programmed oxygen desorption and sorption processes on Pr2-XLaxNiO4 $+\delta$ nickelates
}

Alexandra Usenka, Vladimir Pankov, Vaibhav Vibhu, Aurelien Flura, Jean-Claude Grenier, Jean-Marc. Bassat

\section{To cite this version:}

Alexandra Usenka, Vladimir Pankov, Vaibhav Vibhu, Aurelien Flura, Jean-Claude Grenier, et al.. Temperature programmed oxygen desorption and sorption processes on Pr2-XLaxNiO4 $+\delta$ nickelates. ECS Transactions, Electrochemical Society, Inc., 2019, 91 (1), pp.1341-1353. 10.1149/09101.1341ecst . hal-02337219

\section{HAL Id: hal-02337219 \\ https://hal.archives-ouvertes.fr/hal-02337219}

Submitted on 30 Jul 2020

HAL is a multi-disciplinary open access archive for the deposit and dissemination of scientific research documents, whether they are published or not. The documents may come from teaching and research institutions in France or abroad, or from public or private research centers.
L'archive ouverte pluridisciplinaire HAL, est destinée au dépôt et à la diffusion de documents scientifiques de niveau recherche, publiés ou non, émanant des établissements d'enseignement et de recherche français ou étrangers, des laboratoires publics ou privés. 


\title{
Temperature Programmed Oxygen Desorption and Sorption Processes on Pr2-xLaxNiO ${ }_{4+\delta}$ Nickelates
}

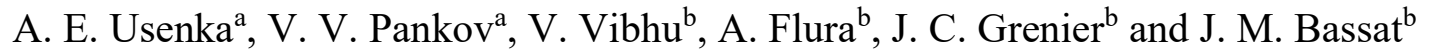 \\ ${ }^{a}$ Belarusian State University, Nezalezhnastsi avenue 4, 220050 MINSK, BELARUS \\ ${ }^{\mathrm{b}}$ CNRS, Univ. Bordeaux, Bordeaux INP, ICMCB, UMR 5026, 33600 PESSAC Cedex, \\ FRANCE
}

\begin{abstract}
The present work is devoted to the investigation of temperature programmed oxygen desorption - sorption (TPD) processes performed on SOFC innovative cathode materials with $\operatorname{Pr}_{2-\mathrm{x}} \mathrm{La}_{\mathrm{x}} \mathrm{NiO}_{4+\delta}$ composition. The experiments were performed using the coulometric titration technique involving an OXYLYT ${ }^{\mathrm{TM}}$ device, over the temperature cycle $20-900-20{ }^{\circ} \mathrm{C}$. The considered parameters were the time and temperature dependences of both the titration current and the oxygen over-stoichiometry. TPD spectra of $\operatorname{Pr}_{2-\mathrm{x}} \mathrm{La}_{\mathrm{x}} \mathrm{NiO}_{4+\delta}(\mathrm{x} \neq 0)$ exhibited two sharp peaks (maxima) of titration current with excellent resolution at $\mathrm{p}\left(\mathrm{O}_{2}\right)=50 \mathrm{~Pa}$, induced by removal of oxygen from different sites of the crystal lattice. TPD spectrum of $\mathrm{Pr}_{2} \mathrm{NiO}_{4+\delta}$ recorded under the same conditions drastically differs from the spectra of $\operatorname{Pr}_{2-x} \mathrm{La}_{x} \mathrm{NiO}_{4+\delta}$ as four sharp maxima of titration current are detected. The TPD spectra of $\operatorname{Pr}_{2-x} \mathrm{La}_{\mathrm{x}} \mathrm{NiO}_{4+\delta}$ then strongly depend on the nature of the rare-earth (La or Pr) in link with the oxygen over-stoichiometry amount.
\end{abstract}

\section{Introduction}

Due to their high oxygen ion diffusivity and electronic conductivity at high temperature, the mixed ionic-electronic conducting (MIEC) lanthanide nickelates $\mathrm{Ln}_{2} \mathrm{NiO}_{4+\delta}$ with $\mathrm{K}_{2} \mathrm{NiF}_{4}$-type structure can be used as solid oxide fuel cell (SOFC) cathodes, separation membranes or oxygen sensors $(1-6)$.

Oxygen exchange with atmosphere, i.e. desorption-sorption processes, obviously depends on the crystallographic structure as well as on the oxygen non-stoichiometry of the oxides. Temperature programmed desorption (TPD) followed by solid electrolyte coulometry/potentiometry gives valuable data on the oxygen exchange processes: temperature at which oxygen releases (desorption), stoichiometry changes and structure transition occur (7). Interestingly it also allows estimating the nature of desorpted oxygen species with respect to their mobility (8).

To investigate oxygen TPD and ionic transport in MIEC oxides being induced by a chemical potential gradient, it is convenient to use the multifunctional solid electrolyte device OXYLYT ${ }^{\mathrm{TM}}$ (GmbH SensoTech, Germany) (7-13). It acts both as independent and supplementary technique to thermo-gravimetry, gaseous chromatography, $\mathrm{X}$-ray and 
neutron diffraction in a wide range of temperature and oxygen partial pressure (8). A comprehensive review of OXYLYT ${ }^{\mathrm{TM}}$ and OSEC (Oxygen Solid Electrolyte Coulometry) devices application for investigation of various compounds has been reported by Vashook et al. (8).

Possible ways of application of OXYLYT ${ }^{\mathrm{TM}}$ or OSEC devices were for instance briefly described in the work of Teske (7), where properties of perovskite-like cuprates $\mathrm{Y}-\mathrm{Ba}-$ $\mathrm{Cu}-\mathrm{O}$ were investigated. For example, the time dependence of oxygen exchange gave useful informations about oxygen diffusion in the materials. Spectra of temperature programmed desorption and sorption (TPD) detected the oxygen variation with temperature. According to the authors, TPD spectra of $\mathrm{Y}-\mathrm{Ba}-\mathrm{Cu}-\mathrm{O}$ could be associated with series of structural and conductivity transitions.

Refs $(9,10)$ described the operating modes of the OSEC device that are required to build $\mathrm{p}-\mathrm{T}-\delta$ diagrams and to investigate the thermodynamic properties of mixed nonstoichiometric oxides. For instance, a tentative analysis of oxygen non-stoichiometry and electrical conductivity of the binary strontium cobalt oxide $\mathrm{SrCoO}_{\mathrm{x}}$ has been performed in ref. (11). The authors demonstrated strong evidence of correlation for maxima in TPD spectra (within the temperature range $500-950{ }^{\circ} \mathrm{C}$ ) with phase transitions of the compound and the relationship of a maximum at temperature above $950{ }^{\circ} \mathrm{C}$ with an order-disorder transition of the cubic high-temperature phase.

Regarding nickelates with $\mathrm{K}_{2} \mathrm{NiF}_{4}$ - type structure, oxygen non-stoichiometry combined with electrical conductivity measurements were performed on $\mathrm{La}_{2-x} \mathrm{Sr}_{\mathrm{x}} \mathrm{NiO}_{\mathrm{y}}$ and $\mathrm{Pr}_{2-\mathrm{x}} \mathrm{Sr}_{\mathrm{x}} \mathrm{NiO}_{\mathrm{y}}$ series using OXYLYT ${ }^{\mathrm{TM}}$ device $(3,12,13)$. TPD spectra allowed concluding about the existence of weakly bonded oxygen, capable to reversibly exchange with the gas phase at temperature as low as $250{ }^{\circ} \mathrm{C}$.

The present work is devoted to the investigation of oxygen TPD in $\operatorname{Pr}_{2-x} \mathrm{La}_{x} \mathrm{NiO}_{4+\delta}(0 \leq$ $\mathrm{x} \leq 2$ powders by coulometric solid electrolyte technique, i.e. using device OXYLYT ${ }^{\mathrm{TM}}$.

\section{Experimental}

High purity powders were prepared via the citrate-nitrate route (modified Pechini method) starting from the precursors $\mathrm{Pr}_{6} \mathrm{O}_{11}$ (Aldrich chem, 99.9\%), $\mathrm{La}_{2} \mathrm{O}_{3}$ (Strem Chemical, 99.99\%) and $\mathrm{Ni}\left(\mathrm{NO}_{3}\right)_{2} \cdot 6 \mathrm{H}_{2} \mathrm{O}$ (Acros Organics, 99\%). The lanthanide oxides $\left(\mathrm{Pr}_{6} \mathrm{O}_{11}\right.$ and $\left.\mathrm{La}_{2} \mathrm{O}_{3}\right)$ were pre-fired at $\mathrm{T}=900{ }^{\circ} \mathrm{C}$ overnight to remove the water content because of their highly hygroscopic nature. After the combustion step of the nitrate-citrate mixture, a final annealing at $1200{ }^{\circ} \mathrm{C}$ for $12 \mathrm{~h}$ in air was carried out. Phase purity of the oxides was confirmed by X-ray diffraction using a PANanalytical X'pert MPD diffractometer with $\mathrm{Cu}-\mathrm{K} \alpha$ incident radiation. Further details are given in ref. (14).

The room temperature oxygen over-stoichiometry of the synthesized oxides was determined either by iodometric titration (6) or by thermo-gravimetry analysis (TGA) measurements performed under $\mathrm{Ar} / 5 \% \mathrm{H}_{2}$ flow with a SETARAM setup (MTB 10-8 balance). Both values (table I) are in very good agreement. 
Table I. Oxygen over-stoichiometry $(\delta)$ determined on $\operatorname{Pr}_{2-\mathrm{x}} \mathrm{La}_{\mathrm{x}} \mathrm{NiO}_{4+\delta}$ powders at room temperature in air.

\begin{tabular}{cccc}
\hline Sample & TGA & Iodometry & Average \\
\hline $\mathrm{La}_{2} \mathrm{NiO}_{4+\delta}$ & 0.16 & 0.16 & 0.16 \\
$\mathrm{Pr}_{0.5} \mathrm{La}_{1.5} \mathrm{NiO}_{4+\delta}$ & 0.17 & 0.17 & 0.17 \\
$\operatorname{Pr}_{1.0} \mathrm{La}_{1.0} \mathrm{NiO}_{4+\delta}$ & 0.19 & 0.19 & 0.19 \\
$\operatorname{Pr}_{1.5} \mathrm{La}_{0.5} \mathrm{NiO}_{4+\delta}$ & 0.21 & 0.20 & 0.205 \\
$\operatorname{Pr}_{2} \mathrm{NiO}_{4+\delta}$ & 0.27 & 0.25 & 0.26 \\
\hline
\end{tabular}

Oxygen desorption-sorption processes with atmosphere were studied on $\mathrm{Pr}_{2-\mathrm{x}} \mathrm{La}_{\mathrm{x}} \mathrm{NiO}_{4+\delta}$ with OXYLYT ${ }^{\mathrm{TM}}$ device over the temperature cycle $20-900-20{ }^{\circ} \mathrm{C}$. The required value of oxygen partial pressure set by coulometry dosing was $50 \mathrm{~Pa}$. Argon was used as a carrier gas and air was used as a comparison gas. The considered parameters were the time and temperature dependences of both the titration current $\left(I_{2}\right.$ in Fig. 1) and / or the oxygen over-stoichiometry. To simplify further discussions, the dependence will be called TPD spectra (7), the spectra data concerning not only desorption but also oxygen sorption.

Fig. 1 shows a scheme of the measurement system of OXYLYT ${ }^{\mathrm{TM}}$ operating in coulometric regime. The measurement system consists of two identical solid electrolyte cells, each one using a tube made of $8 \mathrm{~mol} . \% \mathrm{Y}_{2} \mathrm{O}_{3}$ stabilized $\mathrm{ZrO}_{2}(8 \mathrm{YSZ})$. Each cell has a pair of oxygen pumping $\left(I_{i}\right.$, pump zone) and potential measurement ( $U_{\mathrm{i}}$, gauge zone) electrodes. Porous Pt partly covering areas of inner and outer walls of YSZ tube ensures the electrical contacts and serves as electrode components.

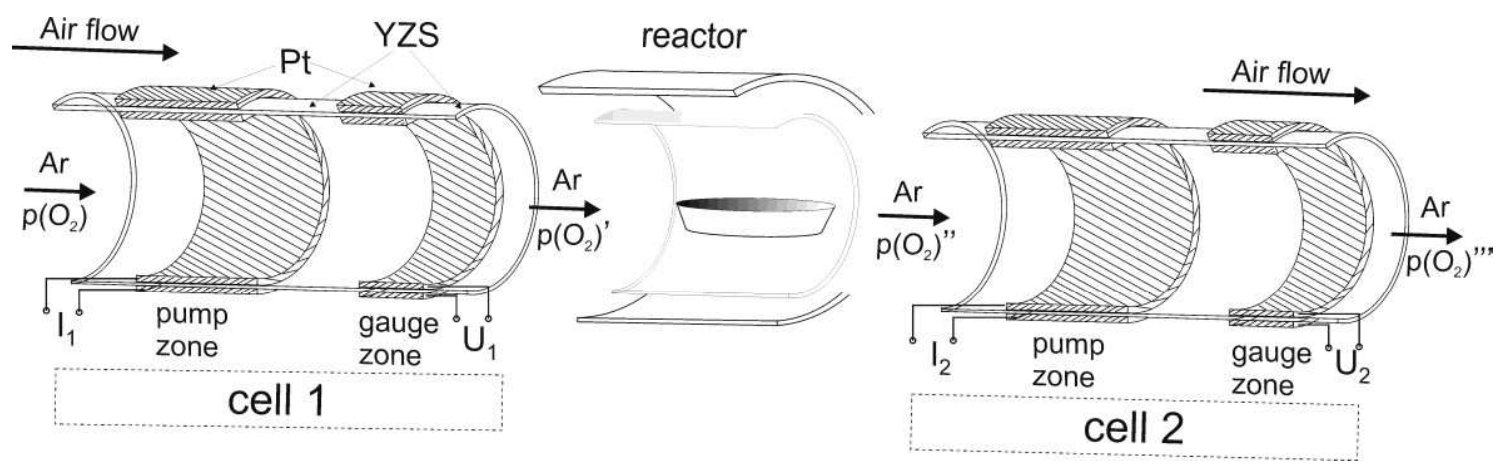

Figure 1. Scheme of OXYLYT ${ }^{\mathrm{TM}}$ operating in coulometric mode.

The cells allow stabilizing a steady-state gas flow with a given oxygen concentration by presetting the electrode voltage $\left(U_{\mathrm{i}}\right)$ at a known temperature. The voltage is controlled by feedback adjustment of the coulometric titration current $\left(I_{\mathrm{i}}\right)$ between the oxygenpumping electrodes.

The experimental reactor and the cells are connected by stainless steel capillaries. If the reactor with a sample is placed between two such cells, the oxygen partial pressure can vary in a wide range (8). The temperature of the reactor can be selected independently of the cells temperature. 
Any oxygen partial pressure $\mathrm{p}\left(\mathrm{O}_{2}\right)$ in the in-flowing gas (Ar) can be modified in cell 1 by coulometric dosing with $\mathrm{O}_{2}$ to reach the required value $\mathrm{p}\left(\mathrm{O}_{2}\right)^{\prime}$. Cell 2 keeps the required value of oxygen partial pressure $\mathrm{p}\left(\mathrm{O}_{2}\right)^{\prime \prime}$ after the flowing gas has just left the reactor by pumping out or pumping in $\mathrm{O}_{2}$. If no oxygen exchange between the flowing gas and the sample takes place in the reactor, no change in oxygen partial pressure $\left(\mathrm{p}\left(\mathrm{O}_{2}\right)^{\prime \prime}=\mathrm{p}\left(\mathrm{O}_{2}\right)^{\prime}\right)$ is observed and titration current $I_{2}$ keeps constant value. If oxygen desorption occurs, oxygen partial pressure rises in the gas flow of the reactor $\left(\mathrm{p}\left(\mathrm{O}_{2}\right)^{\prime \prime}>\mathrm{p}\left(\mathrm{O}_{2}\right)^{\prime}\right)$ and cell 2 pumps out the $\mathrm{O}_{2}$ excess to the value $\mathrm{p}\left(\mathrm{O}_{2}\right)^{\prime}\left(\mathrm{p}\left(\mathrm{O}_{2}\right)^{\prime \prime}=\mathrm{p}\left(\mathrm{O}_{2}\right)^{\prime}\right)$. The pumping-out procedure is detected through the decrease of $I_{2}$ (titration current) if $U_{2}$ is kept constant. If the sample absorbs $\mathrm{O}_{2}$, oxygen partial pressure decreases in the gas flow of the reactor $\left(\mathrm{p}\left(\mathrm{O}_{2}\right)^{\prime \prime}<\mathrm{p}\left(\mathrm{O}_{2}\right)^{\prime}\right)$ and cell 2 pumps in $\mathrm{O}_{2}$ till reaching the value $\mathrm{p}\left(\mathrm{O}_{2}\right)^{\prime}=\mathrm{p}\left(\mathrm{O}_{2}\right)^{\prime \prime}$ ". The pumping-in procedure is detected through the increase of $I_{2}$ if $U_{2}$ is kept constant.

All oxygen exchange in the reactor should be accompanied by a deviation of the coulometric titration current $\left(I_{2, t}\right)$ from the $\left(I_{2}\right.$, base) value, if $U_{2}$ is kept constant. The oxygen exchanged mass $\left(\Delta m\left(\mathrm{O}_{2}\right)\right)$ may be calculated according to the Faraday's law:

$$
\Delta m_{O_{2}}=\frac{M_{O_{2}}}{F \times z} \times \int_{t_{1}}^{t_{2}}\left(I_{2, b a s e}-I_{2, t}\right) d t=\frac{32}{96485 \times 4} \times \int_{t_{1}}^{t_{2}}\left(I_{2, b a s e}-I_{2, t}\right) d t
$$

Knowing the mass and chemical composition of the investigated sample, the TPD spectra can be readily built.

Prior to the coulometric measurements, powders of $\operatorname{Pr}_{2-\mathrm{x}} \mathrm{La}_{\mathrm{x}} \mathrm{NiO}_{4+\delta}$ were flowed at $800{ }^{\circ} \mathrm{C}$ under air during about $2 \mathrm{~h}$ to prevent the influence of possible contaminations. The following temperature cycle was then applied in order to build the TPD spectra: $i$ ) heating to $900{ }^{\circ} \mathrm{C}$ with a constant rate of $6{ }^{\circ} \mathrm{C} / \mathrm{min}$, ii) isothermal plateau at $900{ }^{\circ} \mathrm{C}$ and iii) cooling down to $20^{\circ} \mathrm{C}$ with the same rate (heating-cooling rate denotes as ' $\omega$ '). Afterwards, each heating-cooling cycle performed for coulometric measurements was carried out in $\mathrm{Ar}$ atmosphere with $\mathrm{p}\left(\mathrm{O}_{2}\right)=50 \mathrm{~Pa}$ at flow rate $48-52 \mathrm{ml} / \mathrm{min}$. The duration times will be detailed in the following when necessary.

TGA measurements were used to compare oxygen over-stoichiometry defined with OXYLYTTM.

\section{Results and discussion}

Fig. 2 shows the TPD spectra recorded for five compositions $(\mathrm{x}=0,0.5,1.0,1.5,2)$ of the $\operatorname{Pr}_{2-x} \mathrm{La}_{x} \mathrm{NiO}_{4+\delta}$ powders, while Table II gathers their oxygen stoichiometry content. In the same atmosphere, plots of TPD spectra are almost similar for $\mathrm{La}_{2} \mathrm{NiO}_{4.16}$ and $\operatorname{Pr}_{2}$ ${ }_{x} \mathrm{La}_{\mathrm{x}} \mathrm{NiO}_{4+\delta}(0.5<\mathrm{x} \leq 1.5)$ but it significantly differs for $\operatorname{Pr}_{2} \mathrm{NiO}_{4.26}$, showing some peculiarities which will be discussed below. 


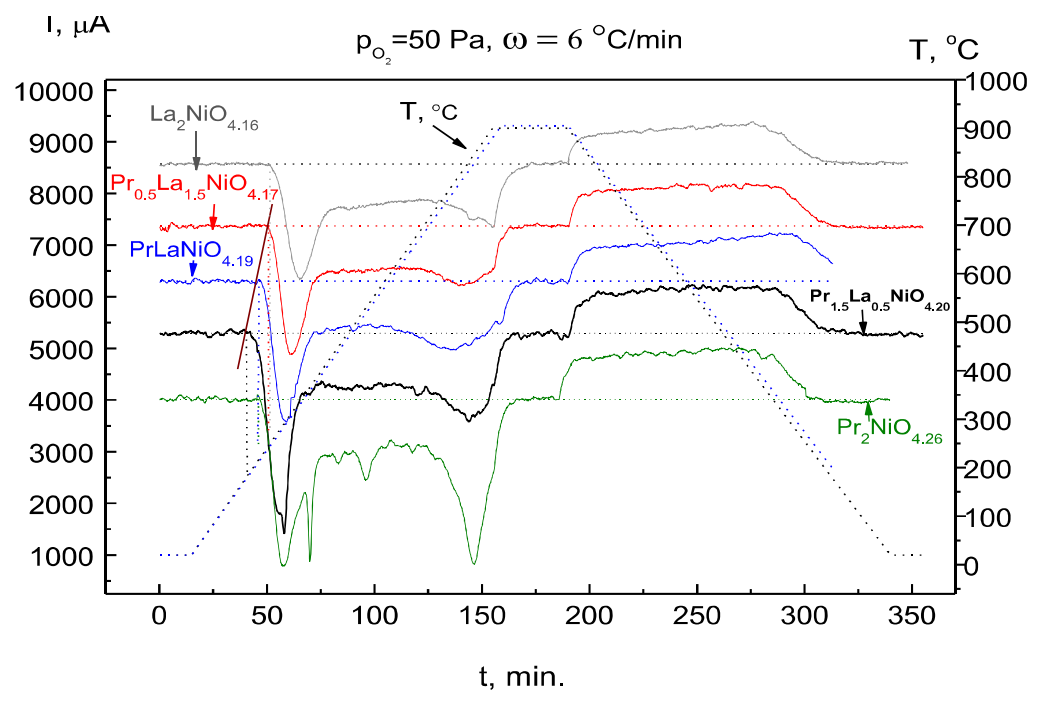

Figure 2. TPD spectra recorded on $\operatorname{Pr}_{2-\mathrm{x}} \mathrm{La}_{\mathrm{x}} \mathrm{NiO}_{4+\delta}(\mathrm{x}=0,0.5,1.0,1.5,2)$ powders in the temperature range $20-900-20{ }^{\circ} \mathrm{C}$ (argon flow, $\mathrm{pO}_{2}=50 \mathrm{~Pa}$, heating-cooling rate $\omega=$ $\left.6{ }^{\circ} \mathrm{C} / \mathrm{min}\right)$.

Prior to further detailed consideration of the spectra, one should pay attention to the titration curves of the samples recorded under cooling conditions. At the beginning of the cooling, and from maximum temperature down to $\sim 290-300{ }^{\circ} \mathrm{C}$, an oxygen sorption is observed. The heated samples are oxygen deficient while they exhibit an oxygen overstoichiometry at room temperature before heating. Due to presence of oxygen in the carriergas, they start to absorb $\mathrm{O}_{2}$ when cooling the powder, which can be seen from values of the titration current which are higher than the base current. Oxygen sorption stops at 290$300{ }^{\circ} \mathrm{C}$, resulting in a quick current dropping to the base current value. Such a thermal behavior is the same for all the samples and will not be more discussed below.

\section{$\underline{\mathrm{TPD} \text { of } \mathrm{La}_{2}} \underline{\mathrm{NiO}}_{4.16}$}

Two main desorption peaks are visible on the TPD spectrum of $\mathrm{La}_{2} \mathrm{NiO}_{4.16}$, located around 240 and $710^{\circ} \mathrm{C}$ (the starting temperature for each peak is chosen to refer on it); one can conclude that under the considered experimental conditions, there are two regions of very intensive and continuous oxygen desorption. The first maximum is located at $330^{\circ} \mathrm{C}$. The second maximum of the titration current cannot be accurately determined, because it is stopped when heating at $900-905^{\circ} \mathrm{C}$. Vashook et al. (12) also observed two desorption maxima in the TPD spectrum of $\mathrm{La}_{2} \mathrm{NiO}_{4}$.15 powder in argon flow with lower oxygen partial pressure $(10 \mathrm{~Pa})$ in the temperature cycle $20-1050-20{ }^{\circ} \mathrm{C}$. The comparison of our results with those of ref. (12) leads to conclude that the real location of the second maximum takes place at a temperature higher than $1050{ }^{\circ} \mathrm{C}$.

The oxygen desorption occurs with an apparent constant rate during heating $\mathrm{La}_{2} \mathrm{NiO}_{4.16}$ in the range $400-700^{\circ} \mathrm{C}$, i.e. between the two previous peaks.

The absorption of $\mathrm{O}_{2}$ during cooling represents a diffuse maximum, i.e. a broad peak in the TPD spectrum (Fig. 2), beginning at $950^{\circ} \mathrm{C}$ on the temperature plateau. From Table 
II, one can see a difference between the initial and final over-stoichiometry of the powders. Because the material is prepared under air, but here cycled under lower $\mathrm{pO}_{2}$, the amount of desorbed oxygen while heating is larger than the amount of absorbed oxygen while cooling, as expected: for instance the initial oxygen over-stoichiometry of $\mathrm{La}_{2} \mathrm{NiO}_{4+\delta}$ is 0.16 , the final one being 0.124 . The influence of the oxygen content in the gas flow can be confirmed by the data reported in ref. (12) for the same material: after cycling under $\mathrm{p}\left(\mathrm{O}_{2}\right)=10 \mathrm{~Pa}$, the final oxygen over-stoichiometry is 0.06 .

Table II. Oxygen over-stoichiometry $(\delta)$ of $\operatorname{Pr}_{2-\mathrm{x}} \mathrm{La}_{\mathrm{x}} \mathrm{NiO}_{4+\delta}(\mathrm{x}=0,0.5,1.0,1.5,2)$ in heating-cooling cycle 20-900-20 ${ }^{\circ} \mathrm{C}$ (argon flow, $\mathrm{pO}_{2}=50 \mathrm{~Pa}$, heating-cooling rate $\omega=6{ }^{\circ} \mathrm{C} / \mathrm{min}$ ).

\begin{tabular}{ccccc}
\hline Sample name & $\begin{array}{c}\text { Initial } \boldsymbol{\delta} \\
(\mathbf{2 0}\end{array}$ & $\begin{array}{c}\boldsymbol{\delta} \text { after heating } \\
\mathbf{( 9 0 0}\end{array}$ & $\begin{array}{c}\left.{ }^{\circ} \mathbf{C}\right) \\
\text { Final } \boldsymbol{\delta} \text { after } \\
\text { cooling }\left(\mathbf{2 0}{ }^{\circ} \mathbf{C}\right)\end{array}$ & $\begin{array}{c}\text { Difference } \\
\text { between the } \\
\text { initial and final } \boldsymbol{\delta} \\
\left(\mathbf{2 0}{ }^{\circ} \mathbf{C}\right)\end{array}$ \\
\hline $\mathrm{La}_{2} \mathrm{NiO}_{4.16}$ & 0.160 & 0.052 & 0.124 & 0.036 \\
$\mathrm{Pr}_{0.5} \mathrm{La}_{1.5} \mathrm{NiO}_{4.17}$ & 0.170 & 0.057 & 0.135 & 0.035 \\
$\mathrm{Pr}_{1.0} \mathrm{La}_{1.0} \mathrm{NiO}_{4.19}$ & 0.190 & 0.059 & 0.148 & 0.042 \\
$\operatorname{Pr}_{1.5} \mathrm{La}_{0.5} \mathrm{NiO}_{4.205}$ & 0.205 & 0.044 & 0.132 & 0.073 \\
$\operatorname{Pr}_{2} \mathrm{NiO}_{4.26}$ & 0.260 & 0.070 & 0.181 & 0.079 \\
\hline
\end{tabular}

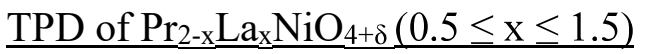

In Fig. 2, two sharper maxima of oxygen desorption (compared to those of LNO) are visible in the TPD spectra of $\operatorname{Pr}_{2-\mathrm{x}} \mathrm{La}_{\mathrm{x}} \mathrm{NiO}_{4+\delta}(\mathrm{x} \neq 0)$. More especially the second one becomes sharper and sharper when the Pr amount increases. In addition, at increasing $\mathrm{Pr}$ content, the start of the first oxygen desorption as well as the first maximum itself (which corresponds to the maximum speed of oxygen release) are shifted to lower temperatures (Table III) compared to $\mathrm{La}_{2} \mathrm{NiO}_{4.16}$. The same conclusion on the temperature range of the second oxygen desorption maximum can be drawn. It should be also noticed that the released oxygen amount during heating increases with the increase of Pr content in $\operatorname{Pr}_{2-x} \mathrm{La}_{x} \mathrm{NiO}_{4+\delta}$. This is clearly visible from the value of the over-stoichiometry $\delta$ before and after heating (see initial $\delta$ and $\delta$ after heating in Table II) and the maxima values of oxygen desorption (Fig. 2). The amount of released oxygen depends on the initial overstoichiometry of the oxides, which in its turn depends on the Pr content, provided the preparation conditions of $\operatorname{Pr}_{2-x} \mathrm{La}_{x} \mathrm{NiO}_{4+\delta}$ are the same. It is also well-known that the oxygen over-stoichiometry $\delta$ in such nickelates depends on the nature of rare-earth cation: the smaller the radius of the rare-earth cation, the higher the oxygen content is. For La, the maximum $\delta$ value is reported to be $0.16-0.18$; for $\operatorname{Pr}$ and $\mathrm{Nd}$ cations $\delta=0.21-0.29$ (1419). In the $\operatorname{Pr}_{2-x} \mathrm{La}_{x} \mathrm{NiO}_{4+\delta}$ solid solution, the $\delta$ value increases when the $\operatorname{Pr}$ amount increases, as expected. 
Table III. Temperature ranges $\left({ }^{\circ} \mathrm{C}\right)$ of the oxygen desorption peaks determined upon heating the $\mathrm{Pr}_{2-\mathrm{x}} \mathrm{La}_{\mathrm{x}} \mathrm{NiO}_{4+\delta}$ samples $(\mathrm{x}=0.5 ; 1 ; 1,5 ; 2)$.

\begin{tabular}{ccccc}
\hline Composition & \multicolumn{2}{c}{ First peak $\left(\mathrm{T}^{\circ} \mathrm{C}\right)$} & \multicolumn{2}{c}{ Second peak $\left(\mathrm{T}^{\circ} \mathrm{C}\right)$} \\
\cline { 2 - 5 } & $\begin{array}{c}\text { Start of oxygen } \\
\text { desorption }\end{array}$ & $\begin{array}{c}\text { Maximum } \\
\text { desorption rate }\end{array}$ & $\begin{array}{c}\text { Start of oxygen } \\
\text { desorption }\end{array}$ & $\begin{array}{c}\text { Maximum } \\
\text { desorption rate }\end{array}$ \\
\hline $\mathrm{La}_{2} \mathrm{NiO}_{4.16}$ & 240 & 340 & 710 & $>1050$ \\
$\mathrm{Pr}_{0.5} \mathrm{La}_{1.5} \mathrm{NiO}_{4.17}$ & 230 & 310 & 680 & 800 \\
$\mathrm{Pr}_{1.0} \mathrm{La}_{1.0} \mathrm{NiO}_{4.19}$ & 210 & 290 & 560 & 770 \\
$\operatorname{Pr}_{1.5} \mathrm{La}_{0.5} \mathrm{NiO}_{4.205}$ & 180 & 288 & 580 & 835 \\
\hline
\end{tabular}

\section{$\underline{\mathrm{TPD} \text { of } \mathrm{Pr}_{2} \mathrm{NiO}_{4.26}}$}

Very interestingly, the TPD spectrum of $\operatorname{Pr}_{2} \mathrm{NiO}_{4.26}$ drastically differs from the previous spectra $(\mathrm{x}<2)$. Four sharp maxima (peaks) of oxygen desorption are observed at the following temperatures: 280, 370, 530 and $840{ }^{\circ} \mathrm{C}$ (labeled 1, 2, 3, 4 in Fig. 3). Two additional prominent peaks (compared to the spectra of PLNO and LNO) are located at 370 and $530^{\circ} \mathrm{C}$ (labeled 2 and 3, Fig. 3).

Besides the four mentioned maxima in the TPD spectrum of $\operatorname{Pr}_{2} \mathrm{NiO}_{4.26}$, our data evidence two local maxima of titration current with low resolution at $\sim 450$ and $670{ }^{\circ} \mathrm{C}$ (labeled 5 and 6, the existence and resolution were confirmed in experimental series with low heating rate, see part 'TPD Spectra Comparison', Fig. 5).

Our TPD spectrum is in rather good agreement with that reported for $\mathrm{Pr}_{2} \mathrm{NiO}_{4+\delta}$ by Sadykov et al. (20). Due to different oxygen partial pressure and inert atmosphere used in our experiments, the observed maxima logically shift to lower temperatures compared to ref. 20. The number of peaks and their position $v s$. temperature in the spectrum reflect the complexity of the dynamical change in the crystal lattice and, as a result, the oxygen ions mobility (connected to their position in the crystal lattice and most likely to the migration/diffusion pathways) while heating. A direct observation of the crystal lattice dynamics and an exact identification of the oxygen positions at atomic scale in nonequilibrium conditions under heating is limited by in situ existing experimental techniques, which makes difficult the interpretation of the TPD spectrum only on the basis of literature data.

According to the available data in literature $(6,20)$, the peaks observed in the temperature range $210-600^{\circ} \mathrm{C}$ would correspond to oxygen removed from interstitial sites located in $\operatorname{Pr}_{2} \mathrm{O}_{2}$ layers (NaCl-type structure) but without any link with the possible lowering of the mean praseodymium charge (which would be between $3+$ and $4+$ ), as supposed by Sadykov et al. (20). Indeed, the charge is only $3+$ in $\operatorname{Pr}_{2} \mathrm{NiO}_{4+\delta}$ whatever the oxygen over-stoichiometry in air at $\mathrm{T}=25-700^{\circ} \mathrm{C}$, as recently experimentally evidenced by XANES studies (21). Combination of experimental and modelling data concerning interstitialcy / interstitial diffusion mechanisms from $(20,22-25)$ allows the following suggestions: the peaks $1-3,5,6$, depicted in Fig. 3 could be likely attributed to mobile "interstitial oxygen" $(\mathrm{O} i)$ and reflect different dynamic positions of $\mathrm{O} i$ in crystal lattice under heating at $\mathrm{T}=\sim 400-650^{\circ} \mathrm{C}$. 


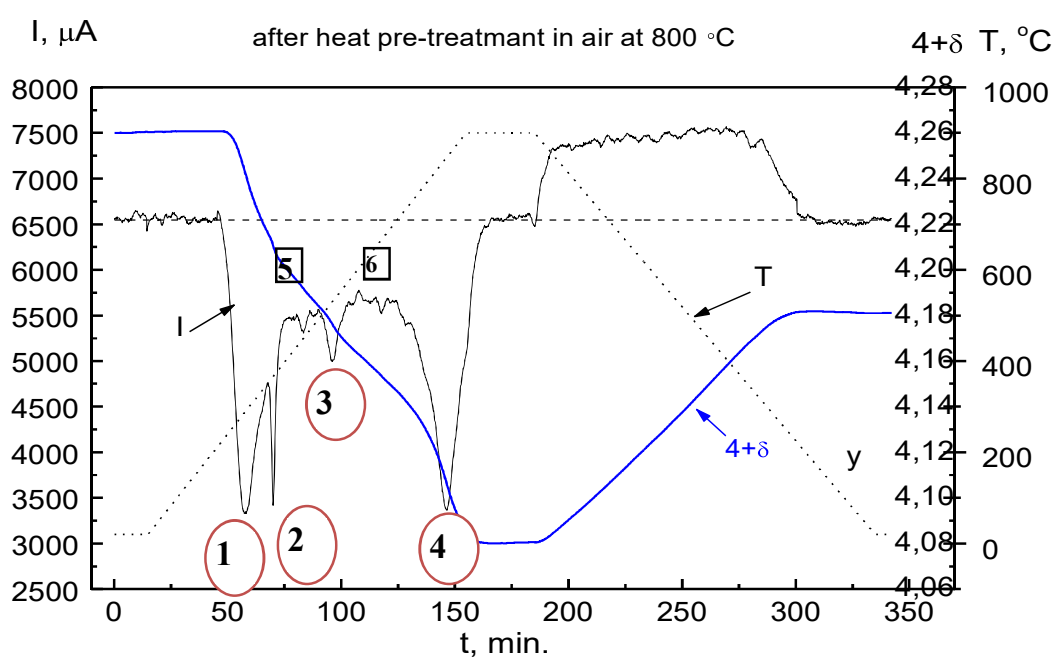

Figure 3. TPD spectra (oxygen partial pressure in argon flow $\mathrm{p}\left(\mathrm{O}_{2}\right)=50 \mathrm{~Pa}$; heating-cooling rate $\omega=6{ }^{\circ} \mathrm{C} / \mathrm{min}$ ) of $\operatorname{Pr}_{2} \mathrm{NiO}_{4.26}$ after annealing in air at $800{ }^{\circ} \mathrm{C}$.

The maximum oxygen desorption at $370{ }^{\circ} \mathrm{C}$, corresponding to the sharp narrow peak ( 2 in Fig. 3), is especially noteworthy. In our experiments, the TPD spectra constantly preserved this peak as compared to $1,3-6$ ones. This peak can be assigned to the orthorhombic-tetragonal phase transition $(22,25)$ in $\operatorname{Pr}_{2} \mathrm{NiO}_{4+\delta}$. According to single crystal neutron diffraction investigations performed by $\mathrm{M}$. Ceretti et al. (23) on $\operatorname{Pr}_{2} \mathrm{NiO}_{4+\delta}$ at temperature around $360{ }^{\circ} \mathrm{C}$, a dynamic decoupling of $\operatorname{Pr}_{2} \mathrm{O}_{2}$ rock salt layer from an embedding matrix of $\mathrm{NiO}_{2}$ layers takes place in this temperature range. Thus, this peak induced by crystal lattice transformation can be found whatever the initial oxygen stoichiometry. In refs. $(16,22)$ it has been confirmed that the initial non-stoichiometry $\delta$ value, typically exceeding 4.20, does not significantly affect the presence of this phase transition.

The maximum oxygen desorption at $840^{\circ} \mathrm{C}(4$, Fig. 3$)$ is supposed to result from oxygen removal from the direct environment of the nickel cations.

\section{Comparison of TPD Spectra}

Summarizing the above-mentioned features concerned with non-monotonous change of oxygen desorption when heating at constant rate, one can correlate the nature of released oxygen with titration current peaks (maxima) in TPD spectra: 1) phase transformation in a material, 2) un-equivalent crystallographic positions of oxygen atoms in the crystal lattice of the compounds. In the case of the phase transformations, an abrupt change in bonding energy of oxygen with the lattice takes place and, as a consequence, an anomaly in the oxygen desorption rate can occur. In the second case, with the increase of temperature, distinct consecutive removal and/or migration of oxygen from interstitial and regular positions can proceed in accordance with the increase in bonding energy of oxygen in the crystal lattice (12). 
The sharp narrow peak matching the phase transition is observed only for PNO and not detected for PLNO phases. A hypothesis is that the amount of oxygen removed during the phase transition for PLNO phases is significantly lower than for PNO (cf. Table 2 and Fig. 2, 4) due to their lower ionic mobility in the attendance of lanthanum cations.

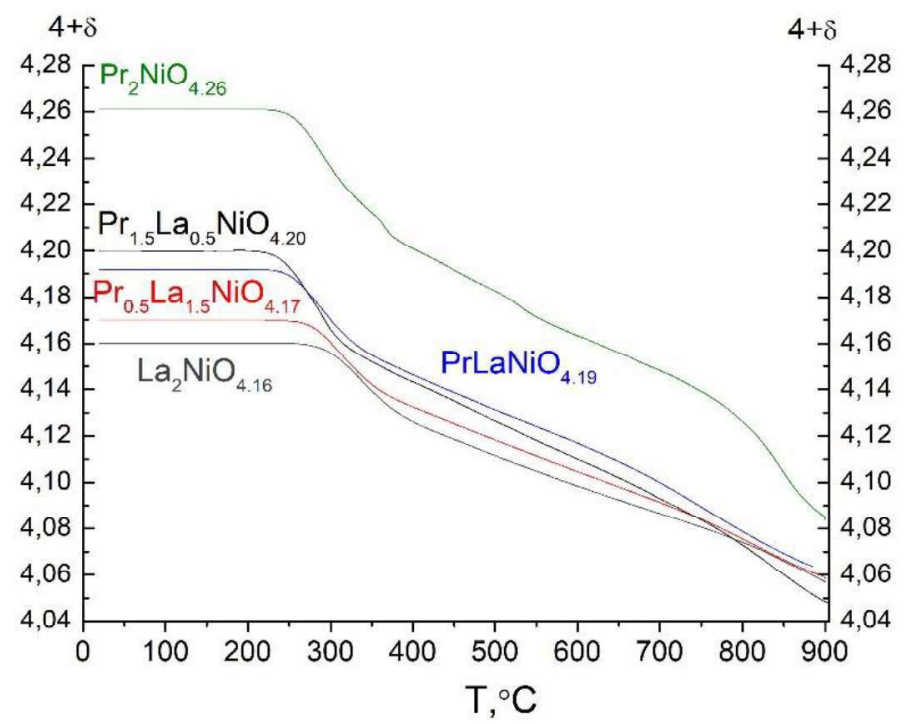

Figure 4. Oxygen non-stoichiometry $\delta$ value $v s$. temperature (converted TPD spectra) of $\mathrm{Pr}_{2-\mathrm{x}} \mathrm{La}_{\mathrm{x}} \mathrm{NiO}_{4+\delta}$ nickelates in argon flow $\left(\mathrm{pO}_{2}=50 \mathrm{~Pa}\right)$ and heating rate $6{ }^{\circ} \mathrm{C} / \mathrm{min}$.

The second reason for the absence of the narrow peak in TPD spectra for $\operatorname{Pr}_{2-\mathrm{x}} \mathrm{La}_{\mathrm{x}} \mathrm{NiO}_{4+\delta}(\mathrm{x} \neq 0)$ could be the vicinity of temperature ranges for weakly-bounded oxygen desorption (first peak) and oxygen removal linked to the phase transition (25). Indeed, from Fig. 2 it can be seen that the location of the first peak shifts towards higher temperature with decreasing $\mathrm{x}$ (for lowest Pr contents, which again supposes a lower mobility of such oxygen in PLNO), and can then overlap the narrow peak of oxygen desorption occurring during the phase transition.

To confirm the existence of the TDP peaks and their resolution for $\operatorname{Pr}_{2} \mathrm{NiO}_{4+\delta}$ and $\mathrm{La}_{2} \mathrm{NiO}_{4+\delta}$, experiments were conducted at lower heating rate $\left(2{ }^{\circ} \mathrm{C} / \mathrm{min}\right)$. As shown in the TPD of PNO (Fig. 5) all oxygen desorption maxima were either present in the temperature range under consideration for the two heating rates $\left(2\right.$ and $\left.6{ }^{\circ} \mathrm{C} / \mathrm{min}\right)$. However, their intensity and shape slightly changed (Fig. 5). Prolonged thermal treatment (depending on the heating rate) results in both cases in the shift of the peaks location to lower temperatures, as well as in a change of the shape of the last maximum (Fig.5(a)).

Most likely, the two sharp maxima in TPD for $\operatorname{Pr}_{2-\mathrm{x}} \mathrm{La}_{\mathrm{x}} \mathrm{NiO}_{4+\delta}(\mathrm{x} \neq 0)$ might be associated to removal of oxygen from different crystallographic positions in these nickelates. Over-stoichiometric oxygen in $\mathrm{La}_{2} \mathrm{NiO}_{4+\delta}$ structure is located in interstitial position with the coordinates $(1 / 4,1 / 4,1 / 4)$, close to layers formed by $\mathrm{NiO}_{6}$ octahedra. These interstitial oxygen ions, apparently, are the most weakly bonded in the nickelate lattice (26). 


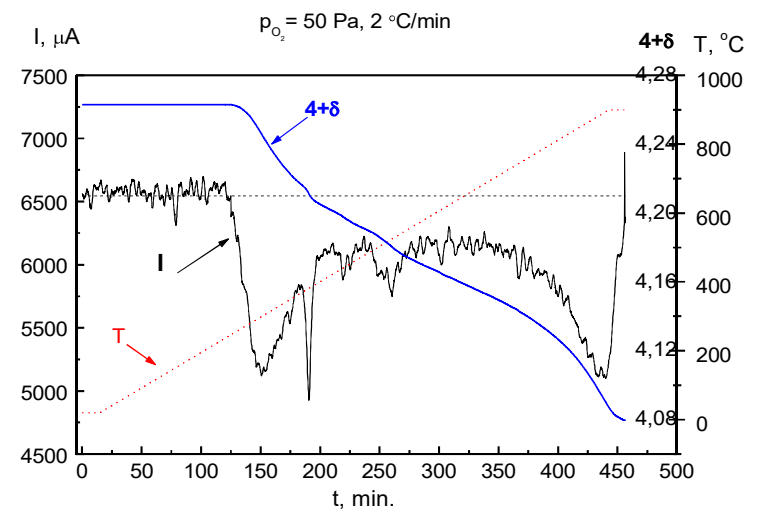

(a)

Figure 5. TPD spectra for $\operatorname{Pr}_{2} \mathrm{NiO}_{4+\delta}$ at $\mathrm{T}=20-900{ }^{\circ} \mathrm{C}$ in argon flow $\left(\mathrm{pO}_{2}=50 \mathrm{~Pa}\right)$ and heating rate $\omega=2$ (a) and $6^{\circ} \mathrm{C} / \mathrm{min}(\mathrm{b})$.

Our suggestion is that during the heating of the nickelates interstitial oxygen ions leave the compound lattice at lower temperatures and cause the occurrence of the first oxygen desorption peak in the range $240-700^{\circ} \mathrm{C}$. After reaching some lower oxygen overstoichiometry content, a further departure of oxygen apparently occurs accounting for the removing of oxygen from its normal (regular) lattice sites. Regular oxygen causes the occurrence of oxygen desorption peaks in the temperature range above $700^{\circ} \mathrm{C}$ as shown in Fig. 2.

When the second oxygen desorption peak occurs in $\operatorname{Pr}_{2-\mathrm{x}} \mathrm{La}_{\mathrm{x}} \mathrm{NiO}_{4+\delta}(\mathrm{x} \neq 0)$, the overstoichiometric content of oxygen $\delta$ drops at $650-700^{\circ} \mathrm{C}$ to a value about $\sim 0.080-0.090$ (Fig. 4, Fig. 6 (a)-(c)). This over-stoichiometric content of oxygen is possibly so strongly linked to the nickelate lattice that it does not result in desorption of oxygen at heating the powders up to temperatures $650-750^{\circ} \mathrm{C}$ (Fig. 1, Fig. 6). In this temperature range, oxygen is more easily removed from the regular lattice sites. 


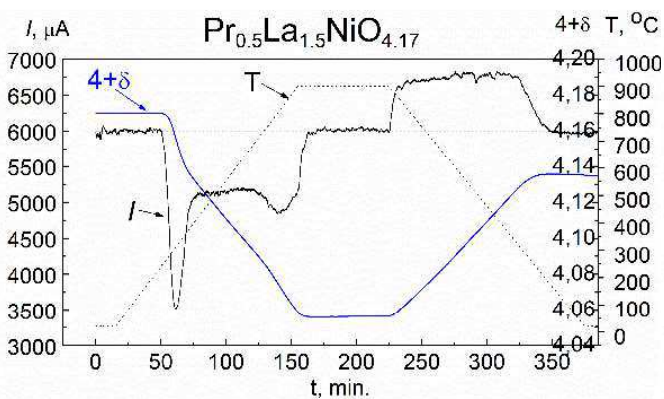

(a)

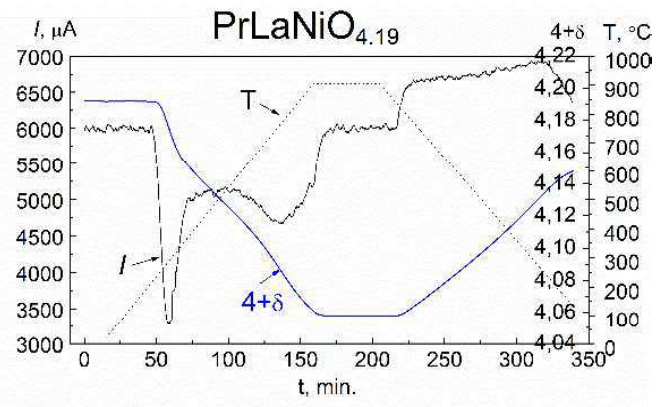

(b)

(c)

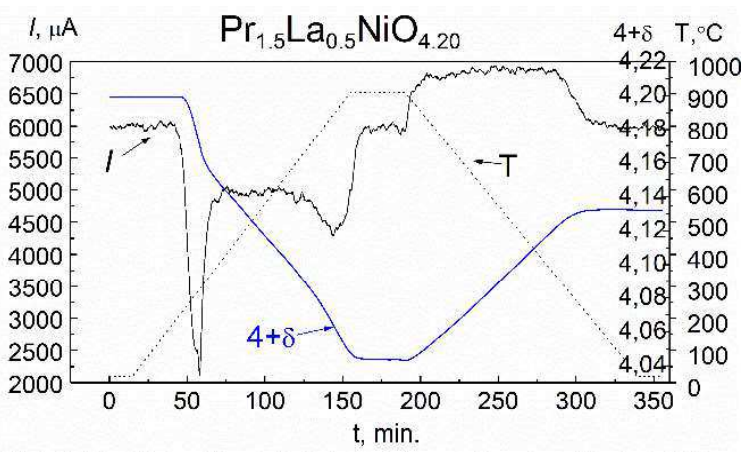

Figure 6. TPD spectra for $\operatorname{Pr}_{2-x} \mathrm{La}_{x} \mathrm{NiO}_{4+\delta}(\mathrm{x}=0.5,1.0,1.5)$ nickelates, including dependence of oxygen nonstoichiometry $4+\delta$ on temperature $\mathrm{T}$, in the temperature cycle 20-900-20 ${ }^{\circ} \mathrm{C}$ in Ar flow $\left(\mathrm{pO}_{2}=50 \mathrm{~Pa}\right)$ and heating-cooling rate $\omega=6{ }^{\circ} \mathrm{C} / \mathrm{min}$.

\section{Conclusions}

TPD spectra of $\operatorname{Pr}_{2-\mathrm{x}} \mathrm{La}_{\mathrm{x}} \mathrm{NiO}_{4+\delta}(\mathrm{x} \neq 0)$ exhibit two sharp peaks (maxima) of titration current with excellent resolution at $\mathrm{p}\left(\mathrm{O}_{2}\right)=50 \mathrm{~Pa}$ that are connected with removal of oxygen from different sites of the crystal lattice. The maxima observed during heating of $\mathrm{Pr}_{2-\mathrm{x}} \mathrm{La}_{\mathrm{x}} \mathrm{NiO}_{4+\delta}$ powders at temperatures $200-700{ }^{\circ} \mathrm{C}$ predominantly result from weakly bonded over-stoichiometric oxygen, i.e. interstitial oxygen in the crystal lattice. The statement might be supported by the fact that, when increasing the Pr amount, whose cationic radius is smaller than that of La, the oxygen over-stoichiometry of the nickelates (synthesized in the same conditions) increases and the oxygen desorption shifts to lower temperature compared to $\mathrm{La}_{2} \mathrm{NiO}_{4+\delta}$.

TPD spectrum of $\operatorname{Pr}_{2} \mathrm{NiO}_{4+\delta}$ recorded under the same conditions drastically differs from the spectra of $\operatorname{Pr}_{2-x} \mathrm{La}_{x} \mathrm{NiO}_{4+\delta}$ with lower Pr contents: three sharp and two local maxima of titration current are located in the range of temperature $210-700{ }^{\circ} \mathrm{C}$ and prominent maximum fourth one above $600{ }^{\circ} \mathrm{C}$. The first maximum in a relatively low temperature range is supposed to have the same nature as for PLNO and might be associated with the removal of interstitial sites with the coordinates $(1 / 4,1 / 4,1 / 4)$, close to layers formed by $\mathrm{NiO}_{6}$ octahedra. The second (narrow) maximum of the TPD at $370{ }^{\circ} \mathrm{C}$ is most probably attributed to the orthorhombic-tetragonal phase transition in $\operatorname{Pr}_{2} \mathrm{NiO}_{4+\delta}$. The peaks observed in the 
temperature range $\sim 400-\sim 650^{\circ} \mathrm{C}$ most likely reflect different (nonequilibrium) migration positions of mobile oxygen from crystal lattice under heating.

The maxima of TPD spectra observed at temperature above $650-700{ }^{\circ} \mathrm{C}$ for each considered nickelate are apparently connected with the removal of oxygen from $\mathrm{NiO}_{6}$ octahedra building perovskite layers. It has been shown that the removal of oxygen from perovskite layers occurs when the lattice maintains some amount of oxygen overstoichiometry $\left(\delta=\sim 0.07-0.09\right.$ for $\operatorname{Pr}_{2-\mathrm{x}} \mathrm{La}_{\mathrm{x}} \mathrm{NiO}_{4+\delta}(\mathrm{x} \neq 0)$ and $\delta=\sim 0.12-0.14$ for $\left.\operatorname{Pr}_{2} \mathrm{NiO}_{4+\delta}\right)$.

\section{Acknowledgments}

This research was supported by the European Community Mobility Programme "Erasmus Mundus Action 2" which has funded mobility grants.

\section{References}

1. A. Chroneos, D. Parfitt, J. A. Kilner and R. W. Grimes. Journal of Materials Chemistry, 20, 266 (2010).

2. J. M. Bassat, M. Burriel, O. Wahyudi, R. Castaing, M. Ceretti, P. Veber and J. A. Kilner. The Journal of Physical Chemistry C, 117, 26466 (2013).

3. V. V. Vashook, I. I. Yushkevich, L. V. Kokhanovsky, L. V. Makhnach, S. P. Tolochko, I. F. Kononyuk and Altenburg, H. Solid State Ionics, 119, 23 (1999).

4. M. Burriel, J. Santiso, M. D. Rossell, G. V. Tendeloo, A. Figueras, and G. Garcia. The Journal of Physical Chemistry C. 112, 10982 (2008).

5. M. Yashima, N. Sirikanda and T. Ishihara. Journal of the American Chemical Society. 132, 2385 (2010).

6. E. Boehm, J. M. Bassat, P. Dordor, F. Mauvy, J. C. Grenier and P. Stevens. Solid State Ionics, 176, 2717 (2005).

7. K. Teske. (. In Materials Science Forum (Vol. 76, pp. 269) (1991).

8. V. Vashook, J. Zosel and U. Guth, Journal of Solid State Electrochemistry, 16, 3401 (2012).

9. M. V. Patrakeev, I. A. Leonidov and V. L. Kozhevnikov. Journal of Solid State Electrochemistry, 15, 931 (2011).

10. Teske, H. Ullmann and N. Trofimenko. Journal of thermal analysis, 49, 1211 (1997).

11. V. V. Vashook, M. V. Zinkevich, H. Ullmann, J. Paulsen, N. Trofimenko and K. Teske,. Solid State Ionics, 99, 23 (1997).

12. V. V. Vashook, S. P. Tolochko, I. I. Yushkevich, L. V. Makhnach, I. F. Kononyuk, H. Altenburg and H. Ullmann. Solid State Ionics, 110, 245 (1998).

13. V. Vashook, J. Zosel, T. L. Wen and U. Guth. Solid State Ionics, 177, 1827 (2006).

14. V. Vibhu, A. Rougier, C. Nicollet, A. Flura, J. C. Grenier and J. M. Bassat. Solid State Ionics, 278, 32 (2015).

15. H. Tamura, A. Hayashi and Y. Ueda. Physica C: Superconductivity, 216, 83 (1993).

16. Y. Toyosumi, H. Ishikawa and K. Ishikawa.. Journal of alloys and compounds, 408, 1200 (2006). 
17. E .Niwa, K. Wakai, T. Hori, K. Yashiro, J. Mizusaki, and T. Hashimoto. Thermochimica Acta, 575, 129 (2014).

18. C. Allançon, P. Odier, J. M. Bassat and J. P. Loup. Journal of Solid State Chemistry, 131, 167 (1997).

19. S. Y. Istomin, O. M. Karakulina, M. G. Rozova, S. M. Kazakov, A. A. Gippius, E. V. Antipov and J. J. Biendicho. RSC Advances, 6, 33951 (2016).

20. V. A. Sadykov, N. F. Eremeev, V. V. Usol'tsev, A. S. Bobin, G. M. Alikina, V. V. Pelipenko and N. F. Uvarov. Russian Journal of Electrochemistry, 49, 645 (2013).

21. T. Ogier, C. Prestipino, S. Figueroa, F. Mauvy, J. Mougin, J. C. Grenier, J. M. Bassat. Chemical Physics Letters, 727, 116 (2019).

22. C. Allançon, A. Gonthier-Vassal, J. M. Bassat, J. P. Loup and P. Odier. Solid State Ionics, 74, 239 (1994).

23. M. Ceretti, O. Wahyudi, A. Cousson, A. Villesuzanne, M. Meven, B. Pedersen and W. Paulus. Journal of Materials Chemistry A, 3, 21140 (2015).

24. S. Xu, R. Jacobs and D. Morgan. Chemistry of Materials, 30, 7166 (2018).

25. A. Flura, S. Dru, C. Nicollet, V. Vibhu, S. Fourcade, E. Lebraud, A. Rougier, J.M. Bassat and J.C. Grenier, Journal of Solid State Chemistry, 228, 189 (2015).

26. Z. Hiroi, T. Obata, M. Takano, Y. Bando, Y. Takeda and O. Yamamoto.. Physical Review B, 41, 11665 (1990). 